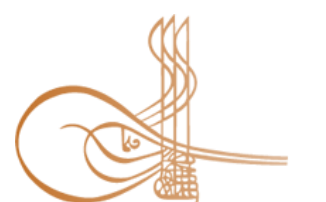

www.turkishstudies.net/religion

\section{Turkish Studies - Comparative Religious Studies}

eISSN: 2667-5544

Research Article / Araştırma Makalesi

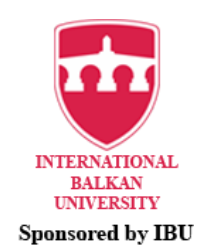

Sponsored by IBU

\title{
İslam Kadın İlmihallerinde Kadının Toplumsal Hayattaki Yeri: Kadın ve Erkek İlmihal Yazarları Üzerine Bir Karşılaştırma*
}

\author{
The Status of Women in Socral Life at Islamic Women's Catechisms: A Comparison Between \\ Female and Male Authors
}

\author{
Senem Gürkan ${ }^{* *}$ - Erkan Perşembe ${ }^{* * *}$
}

\begin{abstract}
Islamic Catechisms are the daily life guides which Muslims can gain knowledge about prayers, belief, ethic and which mention the belief, practice, experience, knowledge and consequences dimensions of religious life. These books can be written for various purposes such as different occupations, necessities, age groups and genders. The aim of this study is to compare the women and men authors of the Islamic Women's Catechisms in terms of the status of women in social life. The samples of this study were five Women's Catechisms, chosen from the population of these boks via criterion sampling technique, one of the puposeful sampling techniques. The two of the authors were women and three of the authors were men. The criteria used for choosing these Ctaechisms were; to be written in Republic Period and in Turkish, to be written for women and to represent the variation of Women's Catechisms. Within this context, this qualitative study conducted through content analysis strategy and feminist epistemology approach as the researcher and the subject to be analyzed is woman, was run within two categories. These categories are women in working life and women in terms of social rights. The readings and analysis demonstrated that women in working life can be subcategorized as labor force participation, gender based occupational discrimination and providing justice for wages; women in terms of social rights can be subcategorized as educational rights, right of succession and proprietary and political rights. The results of the study, in brief, show that both female and male authors reflected gender inequalities to their writings. Another finding is that even if they are female the women, authors mention the problematic fields for women less than those of males.
\end{abstract}

Structured Abstract: The daily life guides that Muslims consult about the prayers, belief and ethic; in other words, the belief, practice, experience, knowledge and consequences dimensions of religious life are

\footnotetext{
* Bu çalışma, ilk yazarın, ikinci yazar danışmanlığında yürüttüğü ve Ondokuz Mayıs Üniversitesi Proje Yönetim Ofisi tarafindan fonlanan (BAP 1904-B; PYO.ILH.1904.17.003) tezinin bir kısmından yararlanılarak üretilmiştir.

** Arş. Gör., Ondokuz Mayıs Üniversitesi, Sosyal Bilimler Enstitüsü, Kadın ve Aile Araştırmaları Anabilim Dalı, Res. Asst. Ondokuz Mayls University, Graduate School of Social Sciences, Department of Women's and Family Studies ORCID 0000-0002-2061-6385

senem.gurkan@omu.edu.tr

**** Prof. Dr., Ondokuz Mayıs Üniversitesi, İlahiyat Fakültesi, Felsefe ve Din Bilimleri Bölümü

Prof. Dr. Ondokuz Mayls University, Faculty of Divinity, Department of Philosophy and Religious Sciences

ORCID 0000-0002-1659-3301

erkanper@omu.edu.tr
}

Cite as/ Atıf: Gürkan, S., Perşembe, E. (2020). İslam Kadın İlmihallerinde Kadının Toplumsal Hayattaki Yeri: Kadın ve Erkek İlmihal Yazarları Üzerine Bir Karşılaştırma. Turkish Studies - Religion, 15(2), 211-222. https://dx.doi.org/10.29228/TurkishStudies.41505

Received/Geliş: 28 January/Ocak 2020

Accepted/Kabul: 20 June/Haziran 2020

Copyright $($ INTAC LTD, Turkey

Checked by plagiarism software

Published/Yayın: 25 June/Haziran 2020

CC BY-NC 4.0 
Catechisms books. These books are written for different purposes such as different occupations, necessities, age groups and genders.

Aim: The aim of this study is to compare the women and men authors of the Islamic Women's Catechisms in terms of the status of women in social life.

Methodology: This research was conducted through qualitative method. The approach that was followed was feminist epistemology approach, as the researcher herself and the subject analysed were both women. Content analysis is the strategy of this research. The data were collected through document analysis method. Within this method, the technique of Miles, Huberman and Saldana (2015) was used: data condensation, data display and conclusion drawing and verification.

The documents that were analysed within the study were selected via Patton's (1990) criterion sampling technique. These criteria were:

- To be written in Republic Period and in Turkish,

- To be written for women,

- To represent the variation of Women's Catechisms.

The five books that meet these criteria are:

The books whose author(s) are female:

- $\quad$ Büyük Kadın İlmihali, Ümmühan Hambeyoğlu, İstanbul, Hikmet Neşriyat, 2001

- $\quad$ Kadın Kaleminden Kadın İlmihali, Sevim Asımgil ve Merve Şahin, İpek, İstanbul, 2005

The books whose author(s) are male:

- $\quad$ Kadın İlmihali, Cemal Öğüt, İstanbul, 1947

- Hanımlara Özel İlmihal, Faruk Beşer, İstanbul, 1993

- $\quad$ Kadın İlmihali, Rauf Pehlivan, İstanbul, 1998, Millî Gazete

Categories: The study was run was run within two main categories. These categories are women in working life and women in terms of social rights. The readings and analysis demonstrated that women in working life can be subcategorized as labor force participation, gender based occupational discrimination and providing justice for wages; women in terms of social rights can be subcategorized as educational rights, right of succession and proprietary rights, political rights.

Figure 1: Categories within the Analysis of Women's Catechisms

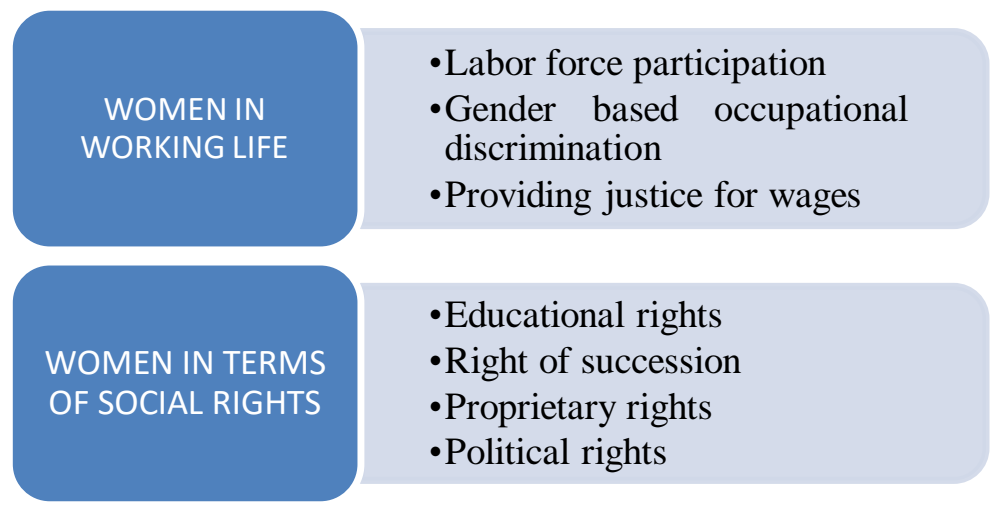

Results: After the analysis on Women's Catechisms, it was found out that two main categories become prominent: one of them was women in working life and the other was women in terms of social rights. The first determination from the first category, that is, women in working life, was labor force participation. Both female and male writers were agree that the place of women is in private sphere, with domestic duties such as housework and the care and bringing up children. Women can work if their husbands allow them to do. However, Pehlivan, one of the male writers, say that he is not supporting the working rights of women. Another 
category is gender based occupational discrimination. Both female and male writers were with the idea that women and men have different kinds of occupations, locating women close to their traditional roles with occupations in the fields of education, health, care and cleaning; whereas men were located as leaders, governors or judges. Regarding the last category, that is, providing justice for wages, only one of the male authors (Beşer) mentioned this subject and he stated that the wages must be distributed with justice, not more or less to men or women, but equal.

Women's social rights are the second main category of this study; with subcategories such as educational rights, right of succession and proprietary and political rights. With regards to educational rights, this subject is not present in female authors. On the other hand, male authors say that they support women's educational rights. Regarding women's right of succession, both male and female authors state that women can get pourparty share half of those of men. Moreover, regarding the proprietary rights of women, all authors say that women can have property. The female writers did not mention anything about the political rights of women, however, male authors state that politics can only be done by men, not women.

In short, the results of the study, in brief, show that both female and male authors reflected gender inequalities to their writings. Another finding is that even if they are female the women, authors mention the problematic fields for women less than those of males.

Keywords: Catethetical Books, Women's Catechisms, gender, women, women and religion.

Öz: İslam ilmihal kitapları, Müslümanların ibadet, inanç ve ahlak sistemlerine ilişkin bilgileri edinebileceği, dini yaşayışın inanç, dini pratikler, tecrübe, bilgi ve etkiler boyutlarına değinen birer gündelik yaşam kılavuzu anlamına gelmektedir. $\mathrm{Bu}$ eserler farklı mesleklere, gereksinimlere, yaş gruplarına ve cinsiyetlere göre yazılabilmektedir. Bu çalışmanın amacı da kadınlar için yazılmış olan İslam Kadın İlmihallerinde, kadının toplumsal hayattaki yerini kadın ve erkek yazarlar açısından karşılaştırmaktır. Çalışmanın örneklemi, amaçsal örnekleme yöntemlerinden ölçüt örnekleme ile seçilen beş tane kadın ilmihalidir. Bu ilmihallerden ikisinin yazarı kadın, üçünün yazarı ise erkektir. Evrenden örneklem çekiminde kullanılan bu ölçütler ise eserlerin Cumhuriyet Döneminde yazılmış ve Türkçe olması, kadınlar için yazılmış olması ve kadın ilmihallerinin çeşitliliğini temsil edebiliyor olmasıdır. Bu bağlamda içerik analizi ile desenlenecek ve araştırmacı ve araştırılan konu kadın olduğu için feminist epistemoloji yaklaşımıyla yürütülecek olan bu nitel çalışma, iki ana ulam çerçevesinde şekillenmiştir. Bu ulamlar çalışma hayatında ve sosyal haklar bağlamında kadındır. Yapılan incelemeler ve okumalar, kadının çalışma hayatı kategorisinin iş gücüne katılım, cinsiyetçi meslek ayrımı ve ücrette adaletin sağlanması gibi alt kategorilerde; sosyal haklar bağlamının ise eğitim ve öğrenim hakkı, miras ve mülkiyet hakkı ve siyasi haklar bağlamında incelenebileceğini ortaya koymuştur. Çalışma sonuçları, çok öz olarak, gerek kadın gerekse erkek yazarların toplumsal cinsiyet eşitsizliğinin etkisini yazılarında gösterdiğini göstermiştir. Kendileri de kadın olmalarına karşın kadın yazarların kadınların problematik alanlarına eserlerinde erkeklerden daha az işledikleri bir diğer bulgudur.

Anahtar Kelimeler: İlmihal, Kadın İlmihali, toplumsal cinsiyet, kadın, din ve kadın.

\section{Giriş}

"İlm" ve "hal" sözcüklerinin birleşiminden oluşan "ilmihal” sözcüğü, sözlükte "davranış" veya "durum bilgisi" olarak tanımlanmaktadır. Hem bir dine inananların dinlerinin inanç, ibadet ve ahlak sistemlerine ilişkin bilgilerinin eğitim ve öğretim usulü, hem de bu eğitim ve öğretim sürecinde kullanılacak kaynak kitabı ifade etmek için kullanılan bu sözcük, zamanla terimleşmiştir. Böylece her kesimden halkın dini konulara ilişkin başvurduğu kitap anlamına gelen "ilmihal" adıyla anılmaya başlamış ve bir telif türü haline gelmiştir (Kelpetin-Arpaguş, 2002: 25-26).

Bir Müslüman nasıl ibadet edeceğinden sosyal hayatta nasıl davranması gerektiğine, aile içindeki tüm ilişkilerindeki hükümlerden inanca dair tüm konulara ilişkin bilgilere bu eserler aracılı̆̆ıyla ulaşabilmektedir. Bu bakımdan ilmihal tarzı eserlerin halkın dini referans kaynağı olduğunu söylemek yanlış olmayacaktır. 
Yine bu eserler, bir yandan inanırların dinine ilişkin bilgi düzeylerinin yükselmesini, bir yandan da İslam hukukuna ait konuları popülerleştirerek ve kitabileştirerek her kesime ulaşmasına katkı sağlamaktadırlar (Okumuş, 2006). Ayrıca bu eserler okurlarına şu tip faydalar sunmaktadır:

"Temel dini bilgiler konusunda hazır bilgilere ulaşabilmek. Delillerinden bulunarak çıkarılmış hükümleri öğrenebilmek. Sorumlu olunan görevleri, ödevleri kolayca öğrenebilmek. Tartışmalardan ve ihtilaflardan uzak olarak bilgileri öğrenmek. İhtiyaç duyulan bilgileri kolay ve çabuk bir şekilde elde etmek. Dini bilgilerin günlük hayata kolaylıkla aktarılmasını sağlamak. Din kültürünün toplumun çeşitli kesimlerine ve özellikle halk arasına yayılmasını sağlamak. Yazıldıkları dönemlerin din anlayışı hakkında bilgi vermek. Dinin halka tebliğ ve irşadını temin etmek." (Bozkurt, 2006: 10).

$\mathrm{Bu}$ tarz eserler dini yaşayışın inanç (belief), dini pratikler (practice), tecrübe (experience), bilgi (knowledge) ve etkiler (consequences) boyutlarına (akt. Günay, 2000: 217) değinmektedir. Bu noktadan hareketle mezheplere, mesleklere, cinsiyetlere, farklı gereksinimlere, yaş gruplarına, engellilik durumlarına göre, hatta farklı konuları ve okur tarzlarını içeren ilmihal tarzındaki eserlere rastlamak mümkündür.

Söz konusu bu ilmihal sınıflandırmalarından cinsiyete göre ilmihal sınıflamasına bakıldığında, literatürde kadınlar için yazılmış, "Kadın İlmihali, Hanımlara (Özel) İlmihal” veya İslam'ın devamlılığını önemsediği aile kurumunda kadının görece önemini göstererek "Kadın ve Aile İlmihalleri”nin bulunduğu görülmektedir.

İlmihal yazarları, kadınlara yönelik yazılan ilmihallerin yalnızca kadınları değil, erkekleri de ilgilendirmesi bakımından hem erkekler hem de kadınlar tarafından okunması gerektiğini söylemişlerdir. Yalnızca isminden hareketle dahi Kadın ve Aile İlmihali tarzındaki eserlerin, kadının aile içindeki özel alandaki konumuna işaret ettiği söylenebilir.

Bu çalışma, kadınlar için yazılan ilmihallerden erkek ve kadın yazarlara ait olanları toplumsal hayat yönünden karşılaştırma amacı taşımaktadır. Bu amaçla seçili ilmihaller üzerine yapılacak olan içerik analizinde kadınların toplumsal hayata ilişkin hangi konularının ele alındığını değinilecek, bu konular eserlerin yazarlarının kadın veya erkek olmalarına göre tartışılacaktır.

\section{Literatür Taraması}

Araştırmamızla en yakın zemini paylaşan çalışma, Çetin (2016) tarafından, kadın ve aile ilmihallerindeki kadın algısını ortaya koyma ana hedefiyle yürütülen çalışmadır. Çalışma varoluşsal düzlem kategorisinde yaratılış, özel haller ve fitne; sosyal düzlem kategorisinde ise evlenme, boşanma, şahitlik gibi konular olmak üzere iki ana kategoride şekillenmiştir. İncele altına alınan eserler ise Asımgil ve Şahin (2013), Beşer (1993), Çalışkan (2005), Karaman (2011), Döndüren (2004), Kara (2010), Pehlivan (2005) gibi kadınlar için yazılmış eserlerdir. Çalışma sonucunda bu eserlerde kadının bir insan olmaktan ziyade toplumsal cinsiyet rolleri çerçevesinde konumlandırıldığı, dolayısıyla Allah'ın değil, kültürel normlarla din anlayışının muhatabına dönüştürdügü örneklerle belirtilmiştir.

Demir (2013) ise çalışmasında, 2001 ve 2011 yılları arasındaki 597 hutbeyi kadın odaklı incelemiştir. Konusunu doğrudan kadınların oluşturduğu 13 hutbenin yanında, 148 adet dolaylı olarak kadını konu olan hutbelerin varlığına rastlanmıştır. Kadına şiddet, eğitim imkanlarına erişim gibi konularla ilgili olduğu ve kadınların anne, eş, çocuk, birey olarak konu alındığı, tarihten örnek kadınlar verildiği, kadına karşı olumlu bir tavrın sergilendiği ve cinsiyetsiz bir dil kullanımının olduğu bulgulanmıştır. Hutbelerdeki toplumsal cinsiyet görünümünün çalış1ldığ 1 bir diğer çalışma ise Ziya ve Korkut (2016) tarafindan yapılmış ve çalışmada 2011 ve 2012 yılları kapsamındaki Türkiye'deki 10 ildeki camide verilen 320 hutbenin 79'u üzerinde inceleme yapmıştır. Araştırma sonuçları, Diyanet'in bu hutbeler yoluyla ataerkil geleneğin varlığını pekiştirdiğini ortaya koymuştur. 
Benzer şekilde Fidan da (2005), Kur'an'da kadını ve kadın imgesini incelemiş, kadının metinlerin konusu olarak dilin bir referansı olduğunu ortaya koymuştur.

Doğan (2012), Jale Şimşek'in Hanım Hanıma Fetvalar (2005) ve Ayşe Gül'ün (2003) Kadın İlmihali adlı eserlerini incelemiş, eserlerde kadın ve erkek cinslerinin biyolojik farklarından dolayı kadının akıldan yoksun olduğu ve bu bakımdan bedensel denetiminin olmadığını ve cinsel olarak çekici olduğunu; erkeğin ise akılcı, üstün cinstir ve denetimi elinde bulunduran cins olduğunu söylemiştir.

\section{Yöntem}

Kadınlara yönelik yazılan ilmihal kitaplarındaki toplumsal hayata ilişkin verileri kadın ve erkek yazarlar açısından karşılaştırma amacını taşıyan bu araştırma, nitel paradigmanın bakış ve süreçleriyle yürütülmüş bir çalışmadır. Ayrıca, çalışma süresince, kadın deneyiminin önemini odağa alarak (Letherby, 2003: 44-45), araştırmacının kendisinin öznel deneyimlerini vurgulayan (Ecevit, 2011: 48) feminist epistemoloji yaklaşımı takip edilmiştir.

\section{Araştırma Deseni}

$\mathrm{Bu}$ çalışma, nitel araştırma türlerinden biri olan içerik analizi (content analysis) ile desenlenmiştir. İçerik analizi, "sözel, yazılı ve diğer materyallerin içerdiği mesajı, anlam ve/ya dilbilgisi açısından nesnel ve sistematik olarak sınıflandırma, sayılara dönüştürme ve/ya çıkarımda bulunma yoluyla sosyal gerçeği araştıran bilimsel bir yaklaşımdır" (Tavşancıl ve Aslan, 2001:22).

\section{Verilerin Toplanması ve Analizi}

$\mathrm{Bu}$ çalışmada veriler doküman analizi tekniğiyle elde edilmiştir.

Veri toplama ve veri analizinin eş anlı olarak yapıldığı bu çalışmada veri analiz modeli olarak Miles ve Huberman'ın (1994) literatüre sunduğu ve sonrasında Saldana ile (2015) geliştirdikleri üç basamaklı nitel araştırma modeli kullanılmıştır. Bu basamaklar verinin özetlenmesi, verinin görsel hale getirilmesi ve sonuçlandırma ve doğrulamadır. İlk basamakta ilmihallerin incelemeye alınacak olan bölümleri ve bu analiz birimleri bir kodlama sistemi oluşturularak özetlenmiş ve temalar/kategoriler oluşturulmuştur. İkinci basamakta ise, ilk basamakta oluşturulan temalar görsel hale getirilmiştir. Son basamakta ise, bu çalışmanın oturtulduğu eleştirel ve yorumlamacı yaklaşım esas alınarak temalar arasında yorumlamalar ve ilişkilendirmeler yapmak suretiyle sonuçlara varılmıştır.

\section{Çalışmanın Evreni, Örneklemi ve Analiz Birimi}

Bu çalışmanın evrenini, Türkiye'de Cumhuriyet Döneminde yazılmış olan kadın (ve aile) ilmihal kitapları oluşturmaktadır.

Çalışmanın örneklemini ise, Patton'un (1990: 182-183) ortaya koymuş olduğu amaçsal örnekleme yöntemlerinden ölçüt örneklemedir.

Söz konusu bu ölçütler şu şekilde verilebilir:

- Cumhuriyet Döneminde yazılmış ve Türkçe olma,

- Kadınlar için yazılmış olma,

- Kadın ilmihallerinin çeşitliliğini temsil edebiliyor olmak.

Tüm bu ölçütleri karşılayan ve bu çalışma bağlamında inceleme altına alınan 5 ilmihal eseri şunlardır:

Yazarı kadın olan kadın ilmihalleri:

- $\quad$ Büyük Kadın İlmihali, Ümmühan Hambeyoğlu, İstanbul, Hikmet Neşriyat, 2001 
- Kadın Kaleminden Kadın İlmihali, Sevim Asımgil ve Merve Şahin, İpek, İstanbul,

Yazarı erkek olan kadın ilmihalleri:

- $\quad$ Kadın İlmihali, Cemal Öğ̈̈t, İstanbul, 1947

- $\quad$ Hanımlara Özel İlmihal, Faruk Beşer, İstanbul, 1993

- $\quad$ Kadın İlmihali, Rauf Pehlivan, İstanbul, 1998, Millî Gazete

\section{Çalışmanın Sınırlııkları ve Varsayımlar}

Bu çalışmanın örneklem seçiminde, yukarıda belirtilen ölçütler bağlamında bir sınırlamaya gidilmiştir. Bu örneklem seçilirken, kadın ve aile ilmihalleri arasında baskı sayısının en fazla olduğu ilmihalin en fazla okunan ilmihal olduğu varsayımı dikkate alınmıştır. Bir diğer sınırlılık ise eserlerin her bölümünün değil, yalnızca toplumsal hayata ilişkin bölümlerinin analize dahil edilmiş olmasıdır.

\section{Kadının Toplumsal Hayattaki Yerine İlişkin Bulgular}

Kadın ilmihalleri üzerine yapılan inceleme ve okumalarda göze çarpan ilk bulgu, kadınlar için yazılmış ilmihallerin büyük çoğunluğunun "Kadın ve Aile İlmihalleri” adıyla piyasaya sürülmüş olmasidir.

Yine aynı çalışma bağlamında, kadının toplumsal hayattaki yerinin, özel alan ve kamusal alan ayrımı temel alınarak işlendiği belirlenmiştir. Bu iş bölümü ışığında kadın özel alanda ev işleri, çocuk, hasta ve yaşlı kimselerin bakım ihtiyaçları ile, devletin kamu gündeminin içeriğine dahil olmayan konumlandırılışlarıyla (Benhabib, 1992: 90), erkek ise ev dışındaki işlerle meşgul olacaktır.

İncelenen ilmihallerde kadının toplumsal yaşama katılımı, çalışma hayatında kadın ve sosyal haklar bağlamında kadın konularında kümelendiği için bu çalışma bu ulamlar etrafında gerçekleştirilmiştir.

\section{1. Çalışma Hayatında Kadın}

"Çalışmak" fiili, gerek anayasamızda (Türkiye Cumhuriyeti Anayasası), gerekse uluslararası belgelerde bir kişilik hakkı olarak ele alınmış, çalışma hayatındaki problemler, çalışmanın yaşa ve cinsiyete göre ayrımcılıklarda bir kırılma noktası olması, emek, çalışma koşulları gibi konular bu tartışmaları oluşturmuştur.

Uluslararası Çalışma Örgütü'nün Dünyada İstihdama ve Toplumsal Duruma Bakış Kadınlarla İlgili Eğilimler 2017 Raporu'na göre, kadınların iş piyasasındaki eşitsiz konumunu dayandırdığı nedenlerden biri toplumsal cinsiyet eşitsizliğidir. Bu eşitsizliğin temelinde ise geleneksel ve kültürel normlar yatmakta, kadın çalışsa dahi asli işinin ev işleri olması kabulü bulunmaktadır (Ibn Ally, 1999: 240; Karaman, 1991). Bu koşullar altında çalışma hayatına dahil olan kadın, erkeklere nazaran farklı ücretlendirme, iş bölümü ve iş koşullarına maruz bırakılacaktır (KSSGM, 1999).

Çalışma hayatı bağlamında kadın ilmihallerinin, kadının iş gücüne katılıp katılamayacağı, cinsiyetçi meslek ayrımı ve ücrette adaletin sağlanması konularını İslami diskurdan ele aldıkları saptanmıştır.

\section{Kadının İş Gücüne Katılımı}

Yapılan incelemeler sonucunda ilmihallerin kadının iş gücüne katılımı noktasında kadın ve erkek yazarlara göre pek bir görüş farkı sergilemediği, her iki cinsiyetten yazarların da kadını öncelikle özel alana (evine), daha sonrasında uygun zamanı ve koşulları varsa kamusal alana (çalışmaya) konumlandırdığı bulgulanmıştır. $\mathrm{Bu}$ minvalde hem kadın yazarlı bir ilmihal (Hambeyoğlu, 2011: 338), hem de erkek yazarlı ilmihaller (Pehlivan, 1998: 45; Beşer, 1993: 22-23) 
kadının çalışmasında dinen sakınca bulunmadığını, fakat kadının asli görevinin ev işleri ve çocukların bakımıyla eğitimi olduğunu savunmaktadırlar.

"Kadın İlmihali” adlı eserinde Pehlivan (1998: 43), kadının çalışması konusunun eşitlikle ilgili olmadığını, hatta bu durumun kadının kendisini erkekle bir tuttuğunu şu sözlerle dile getirmektedir:

"Bugünkü Hıristiyan Avrupa toplumunun kadın hakkında oluşturduğu üç temel prensip: Kadınla erkek arasında eşitlik, kadının ekonomik bağımsızlı̆̆ı, erkekle kadın serbestçe düşüp kalkabilmeli. (...) Hayatta erkeğin faaliyet sahasına dahil olan her işin, kadınlar tarafından da yapılabileceği telkin ediliyordu. Üstelik, kafasına uygun bulduğu, mahiyeti meçhul bir eşitlik fikrinin arkasına takılmak suretiyle insan medeniyetinin bekası için şart olan esas vazifelerinden de uzaklaşmıştır. Böylece kadın, kendi öz şahsiyetini bu gibi faaliyetler içinde eritmiş, kaybetmiştir. Daire ve fabrikalarda çalışmak, serbest ticaret ve iş hayatında erkeklerle boy ölçüşmek, seçimlerle uğraşmak, spor ve oyun meydanlarında kendini gösterip alkış toplamak, kulüplerde, sahnelerde, danslı ve şarkılı toplantılarda vakit öldürmek gibi bitmeyen faaliyet sahneleri. İşte böyle olunca evlilik veya aile yuvası diye bir şey kalır mı?"

Kadının çalışması konusunda ilmihallerde rastlanan bir diğer konu ise, kadının çalışmak için kocasından izin alması gerektiğidir. Hambeyoğlu (2011) ile Asımgil ve Şahin (2013) gibi kadın yazarlar, kocanın ailenin reisi olmasından mütevellit kadının, kocasının izni olmadan çalışmasının mümkün olmayacağını dile getirmişlerdir.

\section{Cinsiyetçi Meslek Ayrımı}

Toplumsal cinsiyet eşitsizliğinin kadının çalışma hayatına getirdiği sınırlılıklardan biri de cinsiyete dayalı meslek ayrımıdır ve pek çok çalışma, bu ayrımın varlığını kabul etmektedir (Sivaslıgil, 2006; Parlaktuna, 2010). Buna göre kadınlar geleneksel rollerini çağrıştıran eğitim, sağlık, bakım ve temizlik hizmetleri alanlarında, erkekler ise siyaset ve kamunun başka alanlarında konumlandırılmışlardır.

Kadın ilmihalleri üzerine yapılan analizler kimi kadın ilmihallerinin doğrudan meslek kollarından bahsetme yoluna gittiğini, kimilerinin ise kadınların yöneticilik yapması konusunu kadının yaratılışı ve fitratına bağladığını göstermiştir.

Kadın yazarlar, kadının doktorluk, sekreterlik yapabileceğini ve hem işveren hem de işçi konumunda bulunabileceğini söylemiş (Asımgil ve Şahin, 2013: 380-381), fakat devlet başkanı, savaşçı, yönetici ve hâkim olamayacağını şu sözlerle belirtmişlerdir: "İslam hukukunda devlet başkanı olmanın bir şartı da erkek olmaktır. (...) Yöneticiler, savaşçılar ve hakimler erkeklerden olacaktır." (Asımgil ve Şahin, 2013: 378).

Yine erkek yazarlar da kadınların doktorluk (Öğüt, 1947: 14), hastabakıcılık ve hemşirelik gibi bakım işleri hizmeti veren meslek kollarında, erkeklerin ise devlet başkanlığı, hakimlik ve çeşitli spor dallarında yer alabileceklerini (Beşer, 1993) dile getirmişlerdir. İslam hukukçularının bazılarının kadının hakimliğini her durumda kabul ettiklerinden, bazılarının ise şahitliğinin geçerli olduğu durumlarda kabul edileceğinden bahsetmişlerdir (Pehlivan, 1998: 506).

Cinsiyete yönelik meslek ayrımını, kadın ve erkeğin yaratılışları gereği farklı fitrata sahip olmalarına bağlayan kadın ilmihalleri yazarları, bu görüşlerini dillendirirken toplumsal cinsiyet eşitsizliğine vurgu yapmışlardır.

Bu yazarlardan, kendisi de bir kadın olmasına karşın Hambeyoğlu (2011), bazı yöneticilik görevlerini kadının değil, fıtratı gereği erkeğin yapması gerektiğini belirtmiştir:

"Kamu görevi icra, idare, kaza, savunma, denetim ve teşri olarak düşünüldüğünde, sonuncusu üzerinde bir ihtilaf söz konusu değildir. İslam'da teşri, vahye, içtihada, şuraya ve devlet 
başkanının tercihine dayanmaktadır. Kadının ictihad yetkisi ve şura üyesi olması hususunda da önemli bir karşı görüş mevcut değildir. Kadının amme göreviyle ilgili olarak en fazla tartışılan konular, hakimlik ve devlet başkanlığıdır. (...) Kadının devlet başkanı, vali, kaymakam gibi yöneticiliklerde bulunması hususu tartışılmış, fikıhçılar bu hususta genellikle menfi görüş belirtmişlerdir. (...) Devlet başkanlığında öncelik erkeklere aittir; bu görevin getirdiği fitri donanım daha ziyade erkeklerde vardır, bununla birlikte ihtiyaç ve zaruret bulunduğunda kapı kadınlara da kapalı değildir." (Hambeyoğlu, 2011: 339). getirmiştir.

Diğer yandan erkek ilmihal yazarı Pehlivan da (1998: 45) aynı görüşte olduğunu dile

\section{Ücrette Adaletin Sağlanması}

Kadının çalışma hayatında karşılaştı̆ğ sorunların bir diğeri, kadının da erkeğin de aynı iş kolunda çalışırken ve aynı işi yaparken, kadının erkekten daha az ücretlendirilmeye tabi tutulması durumudur (Ecevit, 2013:31).

Bu konu hiçbir kadın yazar tarafından dile getirilmemiş, yalnızca bir erkek yazar tarafından ele alınmıştır: "Dünyada iken iş başarırsa kazanç, suç işlerse ceza bulur. Ticarethanesi varsa kadın olduğu için kazanç oranı düşük olmadığ 1 gibi, meşru bir iş görüyorsa kadın olduğu için ücreti de düşük olmaz. Tersine bazı suçlarda kadın erkeğe göre daha az ceza görür.” (Beşer, 1993: 26).

\section{Sosyal Haklar Bağlamında Kadın}

Kadın hakları, özellikle 1789 Fransız İhtilali sonrasında ortaya çıkan özgürlük hareketleriyle gündeme gelmiş, oluşan bu atmosferde kadınlar da haklarını arayış mücadelesine başlamışlardır (Donovan, 2009; Tekeli, 1987: 9-14).

Kadın ilmihalleri, kadının sosyal hakları bağlamında eğitim ve öğrenim hakkını, miras ve mülkiyet hakkını ve siyasi katılımını konu edinmişlerdir.

\section{Eğitim ve Öğrenim Hakkı Bağlamında Kadın}

Kadın yazarlar Hambeyoğlu (2011) ile Asımgil ve Şahin'in (2013), eserlerinde kadının eğitimine spesifik olarak değinmedikleri saptanmıştır.

Erkek yazarlardan Beşer, Hz. Muhammed'in kız çocukların eğitimine önem verdiğini dile getirmiş (Beşer, 1993: 19); Öğüt ise herhangi bir cinsiyet ayrımına yer vermeksizin İslam dininin esası olan ilmin önemi üzerinde durmuştur (Öğüt, 1947: 21).

Pehlivan (1998) ise daha etraflı bir açıklama getirerek tarihten eğitimli kadın örnekleri sunmuştur: "İslam, kadını cehaletten kurtarmış ve onun durumunu yükseltip şerefli kılmıştır. İslam tarihinde bunun örnekleri çoktur. Eğitilmiş Müslüman kadınlar eğitim ve öğretime büyük yardım yapmışlardır." demiş ve tıp, miras, eczacılık, hesap, öğretmenlik gibi konulardan örnekler vermişlerdir."

\section{Miras ve Mülkiyet Hakkı Bağlamında Kadın}

İslam ve kadın konulu eserlerde öne çıkan konulardan biri olan kadının miras ve mülkiyet hakkı, kadın ilmihallerinde de yerini edinmiş ve tıpkı literatürdeki gibi bu eserlere de ihtilaflı bir durum olarak yansımıştır.

Kadının miras hakkı konusundaki bu ihtilafın kaynağı Arap kültürünün etkisidir. Arap kültürü kadına mirastan hiçbir şekilde pay vermezken, İslamiyet kadına erkeğin yarısı kadar hak tanımıştır (Şimşek, 2011: 185) ve kadın ilmihallerinin bazıları Arap kültürünün, bazıları İslamiyetin öngörüleri doğrultusunda bilgi sunmuşlardır. Günümüzde Türkiye Cumhuriyeti Devleti kanunlarına göre kadın da erkek de mirastan eşit pay alabilmektedir. Bu noktada ilmihal yazarlarının, miras payı noktasında anayasayı değil, İslam hukukunu referans aldıkları görülmektedir. 
Kadın ilmihal yazarları, Cumhuriyet döneminde yazılmış olmaları ve bizzat kendileri mirastan pay alacak statüde olmalarına karşın, kadının mirasta erkeğin yarısı kadar pay alması gereğini desteklediklerini söylemektedirler (Hambeyoğlu, 2011: 317; Asımgil ve Şahin, 2013: 383). Hatta Hambeyoğlu (2011: 317) bu duruma bir açıklama getirmiş, erkeğin farklı yükümlülüklerinden dolayı kadına ancak erkeklerin yarısı kadar pay verileceğini söylemiştir: "Mirasta kadına, erkeğin aldığı payın yarısı kadar verildiği durumlarda dengeye riayet edilmiş, gelir ile harcama yükümlülüğ̈̈ arasında adil bir dengeleme yapılmıştır. Kadın, bekar olsun, dul olsun, eş olsun, ana veya kızkardeş olsun...kısacası her halukarda kadının nafakasını temin etmek, yakını olan bir erkeğin üzerine İslam'ın yüklediği bir borçtur. Ayrıca düğün masrafi, mehir verme ve diyet ödeme, erkeğin yükümlülüğü içinde bulunduğu gibi, askerlik görevi de birinci derecede erkekle ilgilidir."

Benzer şekilde erkek yazarların kaleme aldıkları ilmihaller de kadının erkeğe nazaran yarım miras hissesi almalarını uygun gördüklerini dile getirmişlerdir. Örneğin Beşer (1993: 39-40), kadınla erkeğin, karı koca olarak beraber düşünülünce zaten mirastan eşit pay da alsalar, farklı da alsalar evin bütçesine yine aynı para girdiğini, fakat erkeğin toplumdaki görevinin para kazanmak ve evi geçindirmek olduğu için kadının maddi sorumluluğu olmadığının altını çizmiştir. Bu durumda erkekle kadın mirastan aynı oranda pay alırsa, toplum kadınlara mal kaçırıcı gözüyle bakacağından, kadın mirastan pay alırsa erkeğe haksızlık edilmiş olacağını düşündüğünü söylemiştir. Erkek yazarlardan Pehlivan da (1998), mirasta kadının erkeğin yarısı kadar pay alacağını belirterek, bu durumu yine kadınların mali yükümlülüğü olmamasına bağlamıştır.

Kadının mülkiyet hakkı konusunda ise öne çıkan konu mehirdir. Kadın yazarlardan Asımgil ve Şahin (2013), "İslam hukukunda, nikah akdi sebebiyle erkek tarafından verilmek üzere kadının hak kazandığı mala mehir denir. (...) İslam kadına, kendisine rağbet etsinler diye gençliği boyunca bir servet biriktirmesini yakıştıramamış, bilakis erkeklerin ona rağbet ettiklerini hediye -mehirtakdimi ile sembolize etmelerini istemiştir." demektedir.

Erkek yazar Beşer ise (1993) şu söylemlerde bulunmuştur:

“(Kadın) evlenirken ağırlığını koyar, damat adayından istediği kadar mihir alır. Mihir onun Allah'ça belirlenmiş en tabii hakkı ve hayat garantisidir. Harcama sahası, meşru çerçevede tamamen kendi iradesine bağlıdır. Mihrini, ya da varsa diğer mal varlığını hayır yoluyla harcayabileceği gibi ticari işletmelerde kullanabilir, şirketler kurar, şirketlere hisse senetleriyle ortak olur, kazanır ve kazandığını da istediği yerde harcar. Çünkü kendi sosyal güvenliği, kocaya varmakla garanti altına alınmıştır. Ev için ve kendisi için gerekli bütün zaruri harcamalar erkeğin sırtınadır. Erkek, elbiseni ya da süs malzemeni kendi kazancınla al diyemez. Kendi varlı̆̆ 1 ölçüsünde kadının nafakasını sağlamak zorundadır. Sağlayamayacaksa evlenemez. Evlendikten sonra sağlamazsa kadının boşanma talebi olumlu sonuçlanır.".

Pehlivan da (1998), kadının mülk edinme hakkına sahip olduğunu dile getirmiştir.

\section{Siyasi Haklar Bağlamında Kadın}

Siyasi haklar, kadının siyasete katılımı; yani hem seçme hem de seçilme hakkını kapsamaktadır. Kadın ilmihal yazarlarının hiçbiri, kadının siyasete katılımına eserlerinde yer vermemişlerdir.

Erkek yazarlardan ise sadece Pehlivan (1998: 45), reddedici bir tavırla ele almış, "seçimlerle uğraşmak" fiilinin erkeklere mahsus olduğundan, kadınların bu alana katılmalarının erkeklerle boy ölçüşmek olduğunu söylemiştir.

\section{Değerlendirme ve Sonuç}

İslam kadın ilmihallerinde yer alan kadının toplumsal hayattaki yerini, kadın ve erkek yazarlar açısından ele alan bu çalışmanın örneklemine içerik analizi uygulandığında, iki ana konunun 
ortaya çıktığı saptanmıştır. Bu konular çalışma hayatında kadın ve sosyal haklar bağlamında kadın ulamlarıdır.

Çalışma hayatında kadın konusundaki saptamaların ilki, kadının iş gücüne katılımıdır. Bu konuda gerek kadın gerekse erkek yazarlar, kadının asli görevinin özel alanda olduğunu ve bu işlerin ev işleri ve çocukların eğitim ve bakımıyla ilgili olduğunu; kadının eşinden izin aldığ 1 taktirde çalışabileceğini söylemişlerdir. Erkek yazarlardan Pehlivan ise (1998: 43), kadının çalışmasını reddettiğini dile getirmiştir. Bu noktada incelenen kadın ilmihallerinden yapılacak çıkarım, alanyazındaki diğer çalışmalar ile aynı zemini paylaştı̆̆ıdır (Ibn Ally, 1999; Karaman, 1991).

Kadının çalışma hayatındaki yeri konusunda kadın ilmihallerinde yer alan bir diğer tema ise, cinsiyete dayalı bir meslek ayrımıdır. Kadın ve erkek yazarlar, kadınların geleneksel rolleri doğrultusunda eğitim, sağlık, bakım ve temizlik hizmetleri alanlarında, erkeklerin ise fitratları gereği siyaset ve kamunun başka alanlarında (savaşçı, hâkim, devlet başkanı, vb.) konumlandırıldıkları ve bu yönelimin literatürle paralel olduğu tespit edilmiştir (Sivaslıgil, 2006; Parlaktuna, 2010).

Toplumsal cinsiyet eşitsizliği, kadının çalışma hayatı konusunda kendisini ücrette adaletin sağlanması konusunda da göstermiş, bu durum yalnızca Beşer'in eserinde (1993) yerini almış, Ecevit'in (2013) altını çizdiği gibi, kadının da erkeğin de adaletli bir şekilde ücretlendirilmesi gerektiği belirtilmiştir.

Yapılan incelemelerde, kadının sosyal hakları arasında eğitim hakkı, mülkiyet ve miras hakkı ve siyaset hakkı yer almıştır.

Kadının eğitim haklarından yararlanması konusu kadın yazarların eserlerinde yer almamış, erkek yazarlar ise kadının eğitim almasını desteklediklerini dile getirmişlerdir.

Yapılan analizlerden elde edilen bir diğer tespit ise, miras konusunda kadın yazarların da erkek yazarların da kadının mirastan erkeğin yarısı kadar pay alabileceğini deklare ediyor olmalarıdır. Şimşek'in (2011), İslamiyet'in kadına erkeğin yarısı kadar miras hakkı tanıdığını öngördüğü çalışmasıyla paralel sonuçları paylaşan bu çalışmada yazarlar bu durumu, kadının mali yükümlülüğü yokken erkeğin para kazanmak ve evi geçindirmek yükümlülüklerine bağlamışlardır.

Mülkiyet konusunda ise gerek kadın gerekse erkek yazarlar, kadının mülkiyet hakkının olduğundan bahsetmiş ve mülkiyeti özellikle mehir kavramı etrafinda değerlendirmişlerdir. Tüm yazarlar mehri kadının doğal hakkı olarak görürken, Beşer (1993: 19-20) mehri kadının hayat garantisi olarak nitelendirmiştir.

Öte yandan siyasi haklar bağlamında ise kadın ilmihal yazarları bu konuya içeriğinde yer vermemişken, erkek ilmihal yazarları siyasetin erkek işi olduğundan bahsetmişlerdir.

Tüm bu saptamalar, kadının toplumsal hayattaki yerinin, toplumsal cinsiyet eşitsizliğinden kaynaklanarak şekillendiğini göstermektedir. Çetin'in (2016) belirttiği gibi, Kur'an kadını ve erkeği birer insan olarak ele alırken, bu eserlere yapılan incelemede ise kadın ve erkeğin toplumsal cinsiyet rolleri çerçevesinde eşitsiz konumlandırıldıkları bulgulanmıştır.

Ancak bazı konuları kadın yazarlar, kendileri de kadın olmalarına karşın teğet geçmişlerdir. Hatta kadınların bizzat kendileri kadın oldukları için, "içeriden bakış veya içeriden bilgi” (Reinharz, 1992) şeklinde adlandırılabilecek kadınlık deneyimlerine ve bu deneyim ve gerçekliklerin, bu durumlara maruz kalanlarca ele alınması gereğini salık veren (Freire, 1970) epistemolojik temelleri eserlere yansıtmayarak, dikkat çekmeleri gereken bazı konulara erkek yazarlardan daha az yer verdikleri saptanmıştır. Bu durum, kadınların, kendi durumlarını problematik bir alan olarak görmediklerini veya bu durumların farkında olmadıkları olarak yorumlanabilir.

Kadın ilmihal yazarlarının aksine, kadınların problem yaşadıkları alanları ve kadın deneyimlerinin gerçeklğini erkek yazarlar daha etraflıca ele almışlardır. Bu durum erkeklerin 
toplumsal cinsiyet yanlısı olmadıklarını göstermemekte, fakat kadın yazarlara nazaran daha yüksek bir farkındalıkla yazıldığııı göstermektedir.

\section{Kaynakça}

Asımgil, S. ve Şahin, M. (2013). Kadın kaleminden kadın ilmihali. İpek Yay.

Beşer, F. (1993). Hanımlara özel ilmihal. Nun Yay.

Bozkurt, R. (2006). Cumhuriyet Dönemi ilmihal çalışmaları ve problemleri. Yayımlanmamış yüksek lisans tezi, Selçuk Üniversitesi Sosyal Bilimler Enstitüsü.

Çalışkan, H. (2005). Hanımlar ilmihali. Serhat Kitapevi.

Çetin, R. (2016). "Kültürün öznesi ve nesnesi olarak kadın: Kadın ilmihalleri örneği. Dini Araştırmalar Kadın Özel Sayısı. 9-35.

Demir, Z. (2013). "Diyanet hutbelerinde kadın söylemi (2001-2011)". Toplum Bilimleri, 7 (14), 95118.

Doğan, H. (2012). "Popüler İslami yazında kadın bedeni: Kadınlara anlatılan "fitne". Folklor/Edebiyat, 18/69, 87-108.

Donovan, J. (2009). Feminist teori. Aksu Bora, vd. (çev). İletişim Yay.

Döndüren, H. (2004). Delilleriyle aile ilmihali. Erkam Matbaas1.

Ecevit, Y. (2013). "Emek”. Yıldız Ecevit ve Nadide Karkıner (ed.). Toplumsal cinsiyet çalışmaları (s. 24-47). Anadolu Üniversitesi Yay.

Eslen Ziya, H. ve Korkut, U. (2016). "Hutbelerde toplumsal cinsiyet söylemlerinin yapılandırılması". Çiğdem Kağıtçıbaşı, Hülya Şimga, vd. (der.). Kadın odaklı, (s. 241-267). KOÇKAM Araştırmaları Dizisi.

Fidan, H. (2005). Kur'an'da Kadın İmgesi. Yayımlanmamış doktora tezi, Ankara Üniversitesi, Sosyal Bilimler Enstitüsü.

Freire, P. (1970). Pedagogy of the oppressed. Seabury Press.

Gayle Letherby. (2003). Feminist research in theory and practice. Open University Press.

Günay, Ü. (2000). Din sosyolojisi. İnsan Yayınları.

Hambeyoğlu, Ü. (2001). Büyük kadın ilmihali. Hikmet Neşriyat.

ILO (2019). Erişim: 05.10.2018, https://www.ilo.org/wcmsp5/groups/public/---europe/---rogeneva/---ilo-ankara/documents/genericdocument/wcms_542307.pdf

Kara, A. (2010). Ayet ve Hadisler ışı̆̆ında aile ilmihali. Erhan Yayıncılık.

Karaman, H. (1991). "Kadının şahitliği, örtünmesi ve kamu görevi”. İslami Araştırmalar. 5/4, 284291.

Karaman, H. (2011). Aile ilmihali. Timaş Y.

Kelpetin Arpaguş, H. (2002). "Bir telif türü olarak ilmihal tarihî geçmişi ve fonksiyonu". M.Ü. İlâhiyat Fakültesi Dergisi, 22 (1), 25-56.

KSSGM (1999). Çalışmaya hazır işgücü olarak kentli kadın ve değişimi. KSSGM Yayınları.

Mashuq ibn Ally. (1999). "Islam". Peggy Morgan ve Clive Lawton (ed.). Ethical issues in six religios traditions, (s. 220-257). Edinburgh University Press. 
Mehmet Ecevit. (2011). “Epistemoloji”. Yıldız Ecevit ve Nadide Karkıner (ed.). Toplumsal cinsiyet sosyolojisi (s. 32-63). Anadolu Üniversitesi Yayınları.

Miles, M.B. ve Huberman, M. (1994). Qualitative data analysis: An expanded sourcebook. Sage.

Miles, M.B.; Huberman, M. ve Saldaña, J. (2015). Qualitative data analysis-a methods sourcebook. Sage Publications.

Okumuş, E. (2006). “İlmihal sosyolojisi: Bir giriş denemesi -Ömer Nasuhi Bilmen örneği”. Diyanet İlmi Dergi, 42/4, 7-26.

Öğ̈̈t, C. (1947). Kadın ilmihali. Huzur Yay.

Parlaktuna, İ. (2010). “Türkiye'de cinsiyete dayalı mesleki ayrımcıllğın analizi”. Ege Akademik Bakış, 10(4), 1217 - 1230.

Patton, M. (1990). Qualitative evaluation and research methods. Sage.

Pehlivan, R. (1998). Kadın ilmihali. Millî Gazete.

Pehlivan, R. (2005). Kaynaklarıyla büyük kadın ilmihali. Motif Yayınc1lık.

Reinharz, S. (1992). Feminist methods in social research. Oxford University Press.

Saldaña, J. (2011). Fundamentals of qualitative research. Oxford University Press.

Seyla Benhabib. (1992). "Models of public space: Hannah Arendt, the Liberal Tradition, and Jürgen Habermas". Craig Calhoun (ed). Habermas and the Public Sphere. MIT Press.

Sivaslıgil, P. (2006). Türk Milli Eğitim Bakanlı̆̆ı'nca yayınlanan 6., 7. ve 8. sınıf ders kitaplarında cinsiyet ideolojisi, Yayımlanmamış yükseklisans tezi, Çukurova Üniversitesi Sosyal Bilimler Enstitüsü.

Şimşek, S. (2011). Türk Hukukunda ve Avrupa İnsan Hakları Sözleşmesinde mülkiyet hakkı. T.C. Maliye Bakanlığı Yayınları.

Tavşancıl, E. ve Aslan, E.A. (2001). Sözel, yazılı ve diğer materyaller için içerik analizi ve uygulama örnekleri. Epsilon Y.

Tekeli, Ş. (1987). Feminizm 19. yüzyıl klasiklerinden seçmeler. Afa Kadın.

Türkiye Cumhuriyeti Anayasası, Kanun No.: 2709 Kabul Tarihi: 7.11.1982, Erişim: 07.12.2019, https://www.tbmm.gov.tr/anayasa/anayasa_2011.pdf 